\title{
Road Pavement Design in One of Oversea Sewage Treatment Plant
}

\author{
Chengbo Zhang, Cheng Hu, Qiaolin Liu, Zheng Wu
}

Powerchina Chengdu Engineering Corporation Limited, CEC, Chengdu, 610072, China

\begin{abstract}
Three methods are used for Road Pavement Design for access road and internal roads to Dasherkandi Sewage Treatment Plant in Bangladesh, the method, standards and ESA for design of the road are introduced, the issues of design standard for Sewage Treatment Plant, traffic increase rate and seal coat for asphalt concrete of the road are discussed, some of the propose is made to minimize different understanding in execution of the contract, it provides necessary references for similar oversea project in similar country.
\end{abstract}

Keywords: Sewerage Treatment Plant; access road and internal roads; pavement design; standard

\section{Project Introduction}

The Dasherkandi Sewerage Treatment Plant in Bangladesh is one of the largest Sewerage Treatment Plant (STP) in southern Asia, the project are includes of the Sewage Lift Pumping Station, 4.8km long GRP Sewage Conveyance Pipeline, Sewage Treatment Plant and Sludge Incineration system. The design capacity of sewage treatment of the Plant is 500MLD. The Employer is Dhaka WASA, the Consultant is HEC for the Project and the project is run over by Powerchina Chengdu Engineering Corporation Limited, Construction Engineering Corporation (CEC).

According to the contract, the length of the access road is $790 \mathrm{~m}$, the elevation of start of the access road is $6.3 \mathrm{~m}$, the width of the road is $6.3 \mathrm{~m}$, the shoulder of the road is $0.5 \mathrm{~m}$ both sides, the total length of the road is $7.0 \mathrm{~m}$. The existing road is earth road and it will be updated to the permanent asphalt concrete road. The access road is divided to the two sections: The length of the first section of the road is $514 \mathrm{~m}$, this section is part of the planned to be developed new town road; the second section is $276 \mathrm{~m}$ including of the length of the bridge. The access road is the only road to the Sewage treatment Plant. The pavement design for the first section of the road is as same as the township road and the second section of the road is the newly to be developed road and it is as same pavement structure as the internal roads in Sewage Treatment Plant. Since there is shortage of the road construction materials locally, therefore, the local design method and standard has to be considered, the design results is outlined as follows.

\section{Design Condition}

2.1 Flexible pavement design

The flexible pavement design is adopted since the flexible pavement has the self-healing properties. If any deformation occurs in flexible pavement within itself due to heavier load than expected, it can recover it to some extent with time under favorable weather condition but any damage is permanent for rigid pavement. It will be easy for the maintenance even if there are any defects at Operation and Maintenance (O\&M) period and also it will be easy for any

Copyright (C) 2020 by author(s) and Frontier Scientific Research Publishing Inc.

This work is licensed under the Creative Commons Attribution International License (CC BY 4.0).

http://creativecommons.org/licenses/by/4.0/ 
maintenance works in future.

\subsection{Design method}

Pavement design as per Road and Highway Department (RHD) of 2005 is used for the road pavement structure design.

2.3 Maximum sludge per day from STP

According to the design, the maximum sludge per day for the Sewage Treatment Plant is $127.63 \mathrm{~T} / \mathrm{d}$. This value is the basis of the road pavement design of Equivalent Standard Axial Load (ESA) for the plant.

\section{Road Pavement Design}

\subsection{Design life}

The design life for the road shall be 10 years for the feeder road in rural area, but 20 years is adopted to find the maximum traffic volume.

\subsection{The traffic growth rate}

The Traffic growth rate in the Sewage Treatment Plant shall be zero for the Operation and Maintenance period, however $7 \%$ is considered for the estimation of the maximum traffic volume.

\subsection{Cumulative ESA}

The cumulative growth factor under the above condition is:

Cumulative ESA $=[(1+\mathrm{r}) \mathrm{n}-1] / \mathrm{r}$

Taken $n=20$ and $r=7 \%$ in the above formula, the Cumulative ESA for the Sewage Treatment Plant is 41.

\subsection{Design speed of the road}

The design speed for the access road and internal roads inside the Sewage Treatment Plant is $30 \mathrm{~km} / \mathrm{h}$.

3.5 Cross slope of the road

The cross slope of the road proposed is $2.5 \%$ for asphalt concrete road.

Table 1. Average daily traffic in the DSTP in O\&M Periods

\begin{tabular}{|c|c|c|c|c|c|c|c|}
\hline Type of traffic & Flow /day & $\begin{array}{r}\text { Weight of } \\
\text { hauling }(\mathrm{T})\end{array}$ & $\begin{array}{l}\text { Weight of } \\
\text { material to } \\
\text { be taken }(\mathrm{T})\end{array}$ & $\begin{array}{l}\text { ESA } \\
\text { Factor }\end{array}$ & ESAs/ day & Annual ESAs & Purpose \\
\hline $\begin{array}{c}\text { Large Truck } \\
\text { with dual axel } \\
(15 \mathrm{~T}) \\
\end{array}$ & 9 & 15 & 135 & 4.8 & 43.2 & 15768 & $\begin{array}{c}\text { To take residue } \\
\text { away }\end{array}$ \\
\hline $\begin{array}{l}\text { Medium truck } \\
\text { with single axle } \\
(10 \mathrm{~T})\end{array}$ & 3 & 10 & 30 & 4.62 & 13.86 & 5058.9 & $\begin{array}{l}\text { For necessary } \\
\text { maintenance }\end{array}$ \\
\hline Light truck (5T) & 4 & 5 & 20 & 1 & 4 & 1460 & $\begin{array}{c}\text { For Laboratory and } \\
\text { others }\end{array}$ \\
\hline $\begin{array}{c}\text { Large bus, } 20 \\
\text { sits } \\
\end{array}$ & 4 & & & 1 & 4 & 1460 & For works \\
\hline Mini bus, 10 sits & 4 & & & 0.5 & 2 & 730 & For visiting \\
\hline \multirow[t]{4}{*}{ Total } & 24 & & 185 & & & 24476.9 & \\
\hline & & \multicolumn{3}{|c|}{ Cumulative growth factors } & & 41.0 & \\
\hline & & \multicolumn{3}{|c|}{ Accumulative ESAs } & & 1003553 & \\
\hline & & \multicolumn{3}{|c|}{ Accumulative ESAs (M) } & & 1.00 & \\
\hline
\end{tabular}

\subsection{ESAs for the Sewerage Treatment Plant}

To taking away dry sludge, 9 No. of heavy trucks with dual axle and with 15 Tons capacity will be far enough. Considering water bower for washing and cleaning, large bus to take staffs to work, and medium truck for necessary 
repair works, and wheel loader for the loading the residue inside the STP, the average daily traffic in the Sewerage treatment plant in Operation and Maintenance period is calculated and shown in Table 1 above.

Table 1 show that the maximum daily traffic inside the STP is 24 Passenger car units (PCU), the results above shows that the ESAs for the Dhaka Sewage treatment plant is 1Million ESAs.

\section{Pavement Structure Design}

4.1 The pavement design as per local method

The pavement structures design is made as per RHD and the result is shown in Table 2 below:

Table 2. Pavement structure design result

\begin{tabular}{|c|c|c|c|c|c|c|c|c|c|c|c|}
\hline $\begin{array}{l}\text { Pavemen } \\
\text { t Layer }\end{array}$ & $\begin{array}{c}\text { Thicknes } \\
\text { s } \\
\text { (mm) }\end{array}$ & $\begin{array}{c}\text { Soaked } \\
\text { CBR } \\
\text { (Min) }\end{array}$ & $\begin{array}{l}\text { TFV } \\
\text { Min } \\
(\mathbf{k N})\end{array}$ & $\begin{array}{l}\text { ACV } \\
\underset{(\%)}{M a x} \\
(\%)\end{array}$ & $\begin{array}{c}\text { LA } \\
\text { A } \\
\text { Min } \\
(\%)\end{array}$ & $\begin{array}{c}\text { PI } \\
\text { Ma } \\
\mathbf{x} \\
(\%)\end{array}$ & $\begin{array}{l}\text { LL } \\
\text { Max } \\
(\%)\end{array}$ & $\begin{array}{l}\text { Compaction } \\
\text { requirement }\end{array}$ & $\begin{array}{c}\text { DCP } \\
\text { Max } \\
\text { Value }\end{array}$ & $\begin{array}{c}\text { Constructio } \\
\mathbf{n} \\
\text { tolerance }\end{array}$ & $\begin{array}{l}\text { RHD } \\
\text { item }\end{array}$ \\
\hline Seal coat & 7 & & & & & & & & & & 3.12 \\
\hline Tack coat & 0 & & & & & & & & & & 3.7 \\
\hline $\begin{array}{l}\text { Asphalt } \\
\text { concrete }\end{array}$ & 40 & & & & & & & 98\% MDD & & & 3.6 \\
\hline $\begin{array}{l}\text { Prime } \\
\text { coat }\end{array}$ & 0 & & & & & & & & & & $\begin{array}{c}3.8 .3 .2 / \\
3.11\end{array}$ \\
\hline $\begin{array}{l}\text { Road } \\
\text { Base } \\
\text { course }\end{array}$ & 175 & $\begin{array}{c}50 \% \text { at } \\
98 \% \mathrm{M} \\
\mathrm{DD} \\
\end{array}$ & 90 & $35 \%$ & $40 \%$ & $5 \%$ & $20 \%$ & & $\begin{array}{l}3.5 \mathrm{~mm} \\
/ \text { blow }\end{array}$ & $\pm 10 \mathrm{~mm}$ & 3.3 .2 \\
\hline $\begin{array}{l}\text { Road } \\
\text { Subbase } \\
\text { course }\end{array}$ & 150 & $\begin{array}{c}25 \% \text { at } \\
98 \% \mathrm{M} \\
\mathrm{DD}\end{array}$ & 75 & $38 \%$ & & $6 \%$ & $25 \%$ & 98\% MDD & $\begin{array}{l}3.5 \mathrm{~mm} \\
/ \text { blow }\end{array}$ & $\pm 15 \mathrm{~mm}$ & 3.2 \\
\hline $\begin{array}{l}\text { Improved } \\
\text { Subgrade }\end{array}$ & 150 & $\begin{array}{c}8 \% \text { at } \\
95 \% \mathrm{M} \\
\mathrm{DD} \\
\end{array}$ & & & & $15 \%$ & $50 \%$ & $95 \%$ MDD & $\begin{array}{l}22 \mathrm{~mm} / \\
\text { blow }\end{array}$ & $\pm 20 \mathrm{~mm}$ & 2.8 \\
\hline $\begin{array}{l}\text { Brick on } \\
\text { End edge } \\
\text { of the } \\
\text { road }\end{array}$ & & & & & & & & & & $\pm 3 \mathrm{~mm} / \mathrm{m}$ & 3.13 .6 \\
\hline Total & 515 & & & & & & & & & & \\
\hline
\end{tabular}

In table above, bitumen of 60/70 shall be used; Type II material is specified for the Base and Subase as per RHD; DCP test frequency is 500m2/1no and Manual method for seal and AC Base course is adopted as per RHD; the application rate of RC 30 or RC70 for tack coat is $0.45 \mathrm{~L} / \mathrm{m} 2$; prime coat of MC30 with spraying rate of $1.0 \mathrm{~L} / \mathrm{m} 2$ shall be applied to the base after compacted and tested; grading of AC and seal coat using manual method is shown in Table 4 below. Application temperature for Bituminous materials shall follow the Technical Specification of RHD.

4.2 The pavement design as per structure number method

As double checking, the pavement design as per structure number as per AASHTO method is used, and when CBR of subgrade is $5 \%$ and over, the total structure thickness is $490 \mathrm{~mm}$ which is close to the local method of total pavement thickness of $515 \mathrm{~mm}$.

4.3 The pavement design as per CBR method of Japanese method

The same result is get when CBR method of Japanese road pavement designs is used.

\section{Construction Design}


5.1 Material for asphalt concrete

Bitumen with penetration of $60 / 70$ is specified for the work.

\subsection{Construction method}

The same construction method as per descripted in the is adopted for the construction.

5.3 Compaction test frequencies

According to the local standard that DCP test can be used for the compaction density test, as least one test at three places in $500 \mathrm{~m}^{2}$ will be test at least once. This test is taken shortest time than any other test method and with high efficiency.

\section{Discussion}

It is noticed that there is two road design standard, one is Local Government Engineering Department (LGED), one is Road and Highway Department (RHD). The road design life shall be 10 -years and traffic increase rate shall be 5\% as per LGED, according to this LGED the road design life is $40 \%$ of that RHD. According to LGED it is not required for AC road, but it is has to be provided according to RHD. The higher standard is used here for the road pavement design for the Sewage Treatment Plant, and the result shall be in conservation.

Since the aggregates shall be imported oversea, therefore, for the economically construction of the road in Bangladesh, the burnt clay brick is allowed to be used as base and subbase material after crushed.

In order to save time and to avoid unnecessary time consumption during execution of the contract, the clear technical specification shall be specified before signing of the contract.

\section{Conclusions}

According to the Pavement Design guide of Road and Highway Department of Bangladesh, the road pavement structure is designed for the road of the first modernized Sewage Treatment Plant in Bangladesh, it is double checked by using CBR and structure number method. The pavement structure from top to down is $7 \mathrm{~mm}$ thick seal coat, $40 \mathrm{~mm}$ thick asphalt concrete, $175 \mathrm{~mm}$ thick Base, $150 \mathrm{~mm}$ thick subbase and $150 \mathrm{~mm}$ thick subgrade. The total thickness of the Pavement is $515 \mathrm{~mm}$. this pavement design will be used for the access road, internal roads inside the Sewage Treatment Plant and the road in Sewage Lift Pumping Station. The minimum compaction shall be $95 \%$ for the improved subbase and $98 \%$ for the other structure layer.

DCP test can be used for the replacement of sand replacement for site density test since this method is quick, fast and with higher efficiencies. The technical speciation shall be determined before sign of the contract to minimum different understanding and time consumption in execution of the contract.

\section{Conflicts of Interest}

The author declares no conflicts of interest regarding the publication of this paper.

\section{References}

[1] Pavement Design Guide for Roads and Highway Department, Government of the Peoples' Republic of Bangladesh, Ministry of communications, Roads and Railway Division, 2005.

[2] Road Pavement Design Manual, LGED, 1999.

[3] Road Design Standard, Rural Road, LGED, JICA, 2005.

[4] Standard Tender Documents Volume 3 of 4 Technical Specification, May 2001; Technical Proposal Vol. 2 of Contract Documents.

[5] Urban Drain Design Manual, Hydraulic Engineering Circular No.22, Third Edition, FHWA-NHI-10-009, September 2009. 